\title{
THE MYSTERY OF RULE 71A(k): THE ELUSIVE RIGHT TO FEDERAL DIVERSITY JURISDICTION OVER CONDEMNATON ACTIONS AUTHORIZED BY STATE STATUTE*
}

THE jurisdiction of the federal courts in diversity cases extends to condemnation suits instituted under a state's power of eminent domain. ${ }^{1}$ But eminent domain is a sovereign prerogative, ${ }^{2}$ and state legislatures often preclude both state and federal judicial consideration of the necessity of the taking by requiring a nonreviewable administrative determination of necessity

*Chicago, R.I. \& P.R.R. v. Stude, 346 U.S. 574 (1954).

1. E.g., Madisonville Traction Co. v. Saint Bernard Mining Co., 196 U.S. 239 (1905); Searl v. School Dist., 124 U.S. 197 (1888) ; Boom Co. v. Patterson, 98 U.S. 403 (1878). See 6 Nichols, Eminent Domain § 27.8[2] (3d ed. 1953).

Jurisdiction attaches under 28 U.S.C. $\$ 1332$ (1952), which provides: "(a) The district courts shall have original jurisdiction of all civil actions where the matter in controversy exceeds the sum of $\$ 3,000$ exclusive of interest and costs, and is between: (1) Citizens of different states...."

For the specific holding that condemnation cases when before a court are civil actions, see Kohl v. United States, 91 U.S. 367, 375 (1875). These cases do not often reach the federal courts. See Advisory Conmittee on Rules for Civil Procenure, Report of Proposed Rule to Govern Condemsination Cases in the Disthict Courts of the Unired States 31 (May 1948); Id. at 33 (Supp. Report, March 1951). Sce also 6 Nichols, Eminent Domaix $\& 27.7$ (3d ed. 1953). Nevertheless, the procedure to govern them has been established by the Federal Condemnation Rule, FED. R. Cw. P. 71A(k), promulgated by the Supreme Court on April 30, 1951. The Rule states:

"Condemnation under State's Power of Eminent Domain. The practice as herein prescribed governs in actions involving the exercise of the power of eninent domain under the law of a State, provided that if the state law makes provision for the trial of ally issue by jury or for trial of the issue of compensation by jury or commission or both, that provision shall be followed."

2. See Boom Co. v. Patterson, 98 U.S. 403 (1878) ; Colorado Midland Ry. v. Jones, 29 Fed. 193 (C.C.D. Col. 1886) ; Mineral Range Ry. v. Detroit \& Lake Superior Copper Co., 25 Fed. 515 (C.C.W.D. Mich. 1885). See also 1 Nichols, EMInent Donsun $\$ \S 1.13$, 3.1 (3d ed. 1950).

Eminent domain is best defined as the sovereign power to take property for public use without the owners consent upon making just compensation. See Scott v. Toledo, 36 Fed. 385, 394 (1888). See also 1 Nichols, Eminent Domain \& 1.11 (3d ed. 1950). It is an absolute right of the government and does not require constitutional recognition. See Boom Co. v. Patterson, 98 U.S. 403, 406 (1878). See also 1 Nichols, EMINENT DomaIN $\$ 1.14[2]$ (3d ed. 1950).

However, there are constitutional restrictions on the exercise of the power. The most important of these are the requirements that "No person shall . . . be deprived of life, liberty, or property, without due process of law; nor shall private property be taken for public use, without just compensation." Found in the Fifth Amendment to the United States Constitution and established as a restriction on state power by the Fourtecnth Amendment. U.S. Const. amends. V, XIV. See Scott v. Toledo, 36 Fed. 385, 395 (1888). Moreover, almost every state Constitution contains a similar restriction. See 1 Nicuots, EAIINENT Domain $\$ 4.1$ (3d ed. 1950). 
to precede institution of a condemnation suit. ${ }^{3}$ On the other hand, the issue of compensation is always judicial in nature, and the courts cannot be deprived of their jurisdiction over it. Nevertheless, the legislature may require that a reviewable administrative appraisal be secured before commencement of state judicial action. ${ }^{5}$ It is settled that if this procedure is not required, the suit may be initiated in a federal district court. ${ }^{0}$ Where state law prescribes a prior administrative assessment of just compensation, ${ }^{7}$ however, the proper time for institution of an original action in a federal district court is uncertain.

In the recent case of Chicago, R.I. \& P.R.R. v. Stude, ${ }^{8}$ a Delaware incorporated railroad instituted state condemnation proceedings, following the administrative steps prescribed by an Iowa statute. ${ }^{9}$ The Iowa Commerce Commission approved the necessity of the taking. ${ }^{10}$ The railroad then filed a petition

3. E.g., Porter v. Board of Supervisors, 238 Iowa 1399, 28 N.W.2d 841 (1947). See also 1 Nichols, Eurrnent Domain \$ 4.101 (3d ed. 1950).

4. Monongahela Navigation Co. v. United States, 148 U.S. 312,327 (1892); Railway Steel Spring Co. v. Chicago \& E.I.R.R, 261 Fed. 690 (1919). See also 1 Iicuous, EMInent Dosiain $\$ 4.104$ (3d ed. 1950). But see United States v. Jones, 109 U.S. 513, 519 (1883).

Of course, the issues of whether the constitutional provisions have been complied with and whether the use for which the property is taken is public are also judicial. Sec Shoemaker v. United States, 147 U.S. 282, 298 (1893); See also 1 Nicuols, Esrrivesr DoxiaIN § 4.13[2] (3d ed. 1950); 6 id. §25.1 (3d ed. 1953).

5. Classification of state condemnation rules is difficult since the procedures vary not only among states but also within the same state. The three most common methods are: 1) initial appraisal by a commission with the right of appeal de novo before a jury (20 states) ; 2) trial by jury without previous reference to a commission (18 states) ; 3) trial by a commission appointed by the trial court (10 states). Clark, The Progosed Conden:ration Rule, 10 Onıо ST. L.J. 1, 9 (1949). See also 6 NichoLs, Eurnest Dossan: $\$$ 24.11 (3d ed. 1953). In 1931, 269 different procedures for judicial condemnation and $\mathbf{5 6}$ administrative methods were reported in use in different cases. FIRST Rerort OF J uvictal CouncII of MíchigaN § 46, pp. 55-56 (1931), cited in Adusony Consritree o: Rules for Civil Procedure, Report of Proposed Rule to Govern Condearisition Cases is The District Courts of The United States 18 (Mlay 1948). "These numbers have not decreased." Ibid.

6. Franzen v. Chicago M. \& St. P. Ry., 278 Fed. 370 (7th Cir. 1921). Research discloses this diversity case as the only one instituted originally in a federal district court. However, a number of these cases have been removed to the federal district court. E.g., Searl v. School Dist., 124 U.S. 197 (18s8); Wabash R.R. v. Duncan, 170 F.2d 38 (8th Cir. 1948). See also 6 Nichols, Earrnent Doararn $\$ 27.7$ (3d ed. 1953). These cases could not have been removed unless original jurisdiction was present. Mladisunville Traction Co. v. Saint Bernard Mining Co., 196 U.S. 239 (1905). Therefore these remuval cases necessarily involve the decision that the suit could have been originally instituted in federal court.

7. A plurality of states so require. See note 5 supro.

8. 346 U.S. 574 (1954).

9. Iowa CODE ANN. $\$ 471.6$ (Supp. 1954) gives railways the right to "acquire by condemnation or otherwise so much real estate as may be necessary for the location, construction and convenient use of its railway ...." The procedure for condemnation is established by chapter 472 of the Iowa Code.

10. Chicago, R.I. \& P.R.R. v. Stude, 346 U.S. 574, 575 (1954). Permission of the 
with the county sheriff, who appointed six resident freeholders to assess damages. ${ }^{11}$ Although dissatisfied with the assessment, the railroad deposited it with the sheriff and took possession of the property. ${ }^{12}$ The Iowa statute allows either party to appeal from the sheriff's commission to the state district court, ${ }^{13}$ which tries the case de novo before a jury. ${ }^{14}$ Here, however, the railroad brought a condemnation action in the federal district court. ${ }^{15}$ This court granted the landowner's motion to dismiss the complaint, ${ }^{10}$ apparently on the theory that once a condemnor elects to invoke state condemnation procedures

Iowa Commerce Commission is required before a company can obtain the power to condemn any property. Iow $\Lambda$ Code ANN. $\$ 471.10$ (Supp. 1954).

11. Chicago, R.I. \& P.R.R. v. Stude, 346 U.S. 574, 575 (1954). These steps were required by Iowa CoDE ANN. $\S \$ 472.3 \& 472.4$ (Supp. 1954).

12. Chicago, R.I. \& P.R.R. v. Stude, 346 U.S. 574, 575 (1954). This was permitted by Iowa CODE ANn. $\S 472.25$ (Supp. 1954). That section also provides that the right to take possession shall not be affected by an appeal from the assessment by either party. The sheriff is authorized to hold the money pending an appeal. IOWA CODE ANN. \& 472.28 (Supp. 1954). The commission assessed damages in favor of Stude in the sum of $\$ 23,888.60$. Chicago, R.I. \& P.R.R. v. Stude, 346 U.S. 574, 576 (1954).

13. Iowa Code ANN. § 472.18 (Supp. 1954): "Appeal. Any party interested may, within thirty days after the assessment is made, appeal therefrom to the district court, by giving the adverse party, his agent or attorney, and the sheriff, written notice that such appeal has been taken."

14. E.g., Randell v. Iowa State Highway Commission, 214 Iowa 1, 241 N.W. 685 (1932) ; Hall v. Wabash Ry., 141 Iowa 250, 119 N.W. 927 (1909); Ball v. Kcokuk \& N.W. Ry., 74 Iowa 132, 37 N.W. 110 (1888).

15. On March 6, 1952 the railroad filed notice of appeal with the county sheriff. Chicago, R.I. \& P.R.R. v. Stude, 346 U.S. 574, 576 (1954). On March 7 it filed a complaint in the United States district court. Brief for Petitioner, p. 4, Chicago R.I. \& P.R.R. v. Stude, supra. On March 10 and 11, the railroad served new notices of appeal on the sheriff and the landowner. Id. at 5 . These notices were docketed with the Clerk of the Pottawattamie County, Iowa, District Court on March 11. Ibid. On March 12 the railroad filed in the United States district court a petition for removal to that court of the pending state suits. Id. at 6 . The landowner on March 24 filed in the United States district court motions to dismiss the actions commenced by the complaint and to remand the removed suits to the state district court.

The United States district court dismissed the railroad's complaint, but allowed its petition for removal. Chicago, R.I. \& P.R.R. v. Kay, 107 F. Supp. 895 (S.D. Iowa 1952). The Eighth Circuit affirmed the dismissal but also remanded the removed cases to the state court. The United States Supreme Court affirmed the Eighth Circuit on both grounds. Chicago R.I. \& P.R.R. v. Stude, 346 U.S. 574 (1954).

The Supreme Court held that the railroad was plaintiff in the procedings and consequently not entitled to removal, since 28 U.S.C. $\$ 1441$ (a) (1952) allows only defendants to remove. Although Iowa Code ANs. $\$ 472.21$ (Supp. 1954) labels the landowner plaintiff and the condemnor defendant, and the Iowa Supreme Court has construted the statute to mean that the condemnor is in fact defendant, Myers v. Chicago \& N.W. Ry, 118 Iowa 312, 91 N.W. 1076 (1902), the United States Supreme Court held that for removal purposes federal law must determine who is plaintiff and who is defendant. It then followed the decision in Mason City \& F.D.R.R. v. Boynton, 204 U.S. 570 (1907), in which the condemnor under an identical provision of the Iowa Statute was held to be plaintiff.

16. Chicago, R.I. \& P.R.R. v. Kay, 107 F. Supp. 895 (S.D. Iowa 1952). 
he is precluded from commencing an original federal action.17 Both the Eighth Circuit ${ }^{18}$ and the Supreme Court ${ }^{10}$ affirmed the dismissal, with dissents in each decision. ${ }^{20}$

The Supreme Court apparently restricted its opinion to the procedural holding that the railroad had phrased its complaint in terms of an appeal rather than an original action and that federal district courts have no appellate jurisdiction. ${ }^{21}$ The Court seems to have ignored the question of whether the railroad, having completed the state administrative procedure, could have maintained an original action in federal district court by filing a proper complaint. Moreover, the Court specifically refrained from deciding whether the railroad could have commenced a federal action before finishing the state administrative process, ${ }^{22}$ although both parties argued this as one of the major issues involved. ${ }^{23}$ The landowner contended that to involie federal jurisdiction the railroad should have started in federal court at the outset.24 The railroad claimed that it first had to exhaust its administrative remedies, and that therefore the dismissal of its complaint on the theory that it had "elected" the state procedures would deprive the railroad of its right to a federal adjudication. ${ }^{25}$ Apparently neither party expected a procedural decision.

The Court's decision is unreasonable if based merely on procedural technicality. If correctly drawn pleadings would have been acceptable, as suggested by the dissents, ${ }^{26}$ the Court should have directed the lower court to permit amendment of the complaint, ${ }^{27}$ as the railroad requested in its petition for rehearing. ${ }^{28}$ Since no decisions exist which delineate the procedures appro-

17. Id. at 905. The same is suggested id. at 902 , but here there is also an intimation to the contrary, suggesting that through some undefined process the railroad might invole federal jurisdiction after completing the state administrative proceeding.

18. Chicago, R.I. \& P.R.R. v. Stude, 204 F.2d 116, modified on rehearing, 204 F.2d 954 (8th Cir. 1953).

19. Chicago, R.I. \& P.R.R. v. Stude, 346 U.S. 574 (1954).

20. The dissenters were Chief Judge Gardner in the Eighth Circuit and Justices Black and Frankfurter in the Supreme Court in separate opinions.

21. Chicago, R.I. \& P.R.R. v. Stude, 346 U.S. 574, 580, 581 (1954).

22. Id. at 582 .

23. See Briefs for Petitioner and Respondent, Chicago, R.I. \& P.R.R. v. Stude, 346 U.S. 574 (1954).

24. Brief for Respondent, pp. 9-23, Chicago, R.I. \& P.R.R. v. Stude, 346 U.S. 574 (1954).

25. Brief for Petitioner, pp. 15-30, Chicago, R.I. \& P.R.R. v. Stude, 346 U.S. 574 (1954).

26. Chicago, R.I. \& P.R.R. v. Stude, 204 F.2d 954, 955 (Sth Cir. 1953), aff'd, 34t U.S. 574, 582, 584 (1954).

27. Or the complaint could have been treated as initiating an original action despite its defects, as in Burford v. Sun Oil Co., 319 U.S. 315 (1943). This course vas suggested by the dissent of Chief Judge Gardner, Chicago, R.I. \& P.R.R. v. Stude, 204 F.2d 954, 956 (8th Cir. 1953).

28. The petition for rehearing was denied without comment. Chicago, R.I. \& P.R.R., 347 U.S. 924 (1954). 
priate for invoking federal jurisdiction, ${ }^{29}$ outright dismissal for a technical error seems particularly harsh. In any event, the Court should not have avoided making a substantive decision which would have made clear for the diversity condemnor his rights in federal court.

There are substantive grounds which might prompt a court to deny a federal suit to a condemnor who has had a prior state administrative determination, and it is possible that they influenced the Supreme Court. Since condemnation proceedings are in rem actions, ${ }^{30}$ acquisition of jurisdiction by one court

29. The only reported case in which original federal jurisdiction was involed is Franzen v. Chicago, M. \& St. P. Ry., 278 Fed. 370 (7th Cir. 1921). That case, however, involved a state statute which provided for the initiation of a condemnation action by filing a petition in the county court. Under such circumstances the procedure for invoking federal jurisdiction is clear. See text at note 6 supra. The problems present in the instant case, see text at notes 24 and 25 supra, were not involved in the Fransch case.

Although the cases of Kaw Valley Drainage District v. Metropolitan Water Co., 186 Fed. 315, 323 (8th Cir. 1911), and Hartford v. Montague, 94 Fed. 227, 228 (C.C.D. Conn. 1899), present dictum to the effect that in an original condemmation action federal jurisdiction may not be obtained until the state administrative proceeding has been completed, these cases certainly do not settle the issue. And the various opinions in the instant case show that the question is in doubt. The district court suggested by way of dictum that the condemnor probably could have started in federal district court both before and after it had completed its state administrative proceeding. Chicago, R.I. \& P.R.R. v. Kay, 107 F. Supp. 895, 902, 905 (S.D. Iowa 1952). The latter suggestion is inconsistent with the apparent grounds for its decision. See note 17 supra. In addition the opinion of the Eighth Circuit implied that federal jurisdiction might have been involsed before the completion of the administrative process, Chicago, R.I. \& P.R.R. v. Stude, 20-t F.2d 954 (1954), while the dissent stated that jurisdiction existed after such completion. Although the Supreme Court apparently ignored the problem, see text at notes $22 \& 23$ supra, the dissents evidenced the dilemma. Mr. Justice Black stated that the condemnor was entitled to a federal action after a state administrative decision, Chicago, R.I. \& P.R.R. v. Stude, 346 U.S. 574, 582, 583 (1954). Mr. Justice Frankfurter claimed that federal jurisdiction existed both before and after the state administrative adjudication. Id. at $584,585$.

30. E.g., United States v. Petty Motor Co., 327 U.S. 372, 376 (1946); Duckctt \& Co. v. United States, 266 U.S. 149 (1924); Treasure Co. v. United States, 169 F.2d 437 (9th Cir. 1948); Minnesota v. United States, 125 F.2d 636 (8th Cir. 1942). See also 1 Nichols, Eminent Donrain \$§ 1.142[1], 4.103[2] (3d ed. 1950). The cases abound with statements to this effect. The problem, however, is whether the instant case is an in rem condemnation suit, or merely an in personam ascertainment of damages. The Supreme Court's opinion indicates that it felt the case was more than a daunage determination. Although it did not appear to be concerned with the in rem problen, the Court said: "The petitioner here seems to ignore the means by which it obtaincd the land and seeks to review only the question of damages. It may not separate the question of damages and try it apart from the substantive right from which the claim for damages arose. Nor can it be said that petitioner has fully exercised its power of eminent domain, leaving nothing to be determined but the question of damages. Petitioner has possession but not title to the land. The land does not belong to petitioner until the damages are paid ... ." Chicago, R.I. \& P.R.R. v. Stude, 346 U.S. 574, 581,582 (1954). This is a clear indication that the instant suit must be in rem despite the fact that the only issue before the courts was one of damages. The dissents, however, apparently felt that the suit was not an in rem condemnation proceeding. Id. at 583, 585 .

See discussion in 6 Nichols, Eminent Dumain $\$ 24.1[1]$ (3d ed. 1953). 
may prevent any other court from taking concurrent jurisdiction over the res. ${ }^{31}$ The exercise of jurisdiction by a judicially empowered administrative agent is sufficient to vest exclusive control of the res in the authorizing court." Although the Iowa sheriff's commission does not act under any court mandate, ${ }^{33}$ it may be argued that its control of the res is sufficient to establish the exclusive jurisdiction of the state district court. ${ }^{34}$ The Iowa Supreme Court has decided that the state district court sits in an appellate capacity in reviewing the ap-

31. This is the consequence of holding that an action is in rem. E.g., Wabash R.R. v. Adelbert College, 208 U.S. 38 (1908); Farmer's Loan \& Trust Co. v. Lalke State R.R, 177 U.S. 51 (1900); and see cases cited note 32 infra. See also discussion in Kline v. Burke Constr. Co., 260 U.S. 226, 227 (1922).

But see Franzen v. Chicago, MI. \& St P. Ry., 27S Fed. 370 (7th Cir. 1921), where it is said that a pending state condemnation suit would not be a bar to federal jurisdiction since the state court had not taken possession of the res.

See also Madisonville Traction Co. v. St. Bernard Mining Co., 196 U.S. 239 (1905), involving removal of a condemnation case which was pending in a state county court after a commission's assessment had been completed. The Supreme Court allowed removal after deciding that original federal jurisdiction would have been present. This case is cited in The Supreme Court, 1953 Tern, 68 HARv. L. Rev. 96, 178 (1954), for the proposition that original federal jurisdiction may be invoked after exhaustion of state administrative remedies. However, the Eighth Circuit has stated that the Mfadisonzille proceeding was not simply an administrative action but was a civil suit from the very inception of the state procedure. Kaw Valley Drainage Dist. v. Metropolitan Water Co., 186 Fed. 315, 322 (8th Cir. 1911). Moreover, even assuming that the state procedure involved in Madisonville was simply administrative, the Court is not explicit in its determination of exactly when original jurisdicton would attach. Finally, the problem in that case was simply to determine whether the statutory elements of original jurisdiction were present. The opinion did not necessarily involve the decision that a federal court should not decline to exercise its jurisdiction because a state court's exclusive in rem jurisdiction had previously attached. This question was not even discussed by the Court.

32. E.g., United States v. Bank of New York \& Trust Co., 296 U.S. 463 (1936) (liquidator); Palmer v. Texas, 212 U.S. 118 (1909) (receiver); Department of Financial Institutions v. Mercantile-Commerce B. \& T. Co., 92 F.2d 639 (7th Cir. 1937) (state Department of Financial Institutions).

33. See Iowa Code ANx. $\S \S 472.3,472.4$ (Supp. 1954).

34. In Carthage v. Rainey, 168 F.2d $\$ 41$ (5th Cir.), cert. denied, 335 U.S. 885 (1948), it was held that the state court's jurisdiction over the res dated from the time of the sheriff's seizure of the property. For this reason, the federal court would not talse jurisdiction even though a civil action was commenced there before one was begun in the state court. See also Gillis v. Keystone Mut. Cas. Co., 172 F.2d 826 (Gth Cir. 1949), which apparently held that jurisdiction over the res acquired by the state Insurance Department was sufficient to defeat federal jurisdiction; and see Annot., 11 A.L.R.2d $\$ 63$ (1950), where it is stated that the action of state administrative bodies which acquire jurisdiction of the res by statutory provision but without judicial order will bar later federal cuurt jurisdiction.

But see Gordon v. Washington, 295 U.S. 30 (1935), which approves a court of appeals ruling that possession of the res by the state Secretary of Banking will not oust a federal court of jurisdiction. 
praisal by the sheriff's commission, ${ }^{35}$ and it thus appears that the commission is acting as an arm of the court. ${ }^{36}$

In addition to the in rem doctrine, there are other obstacles which might preclude federal jurisdiction after the completion of state administrative remedies. The courts might literally construe the Iowa statute, which provides that the sheriff's appraisal becomes final if not appealed to the state court. ${ }^{37}$ Or they might adopt the theory of the federal district court in the instant case. That court denied jurisdiction apparently because it felt that proper respect for state-established procedures should prevent a condemnar from instituting an original suit in federal court once the sheriff's assessment had been made. ${ }^{\text {ss }}$

35. Mazzoli v. Des Moines, 63 N.W.2d 218 (Iowa 1954). Four dissenting justices maintained that jurisdiction of the Iowa District Court is in no legal sense appellate. Id. at 220 .

The United States Supreme Court, however, has impliedly held that the jurisdiction of the Iowa District Court is original; for it has allowed the defendant to remove cases which have reached the state court. See note $41 \mathrm{infra.} \mathrm{Removal} \mathrm{would} \mathrm{not} \mathrm{have} \mathrm{been}$ allowed if the court had regarded the suit in the state court as an appenl. See note 42 infra and note 21 supra. See also Buns, JuRisdiction and Practice of the Courts of THE UNited States 125 (5th ed. 1949).

For a square holding that for federal jurisdictional purposes the federal courts will decide what is original and what is appellate, despite state charactarization, see Chicago, M. \& S.P. Ry. v. Drainage Dist., 253 Fed. 491 (S.D. Iowa 1917).

36. Possession of and even title to the property may pass by the commission's actions. See Iowa Code ANw. $\S \S 472.25,472.35,472.38,472.39$ (Supp. 1954).

37. Iowa CODE ANN. $\S 472.17$ (Supp. 1954): "When appraisement final. The appraisement of damages returned by the commissioners shall be final unless appealed from."

See also id. $\$ 472.18$, regarding appeals, quoted note 13 supra.

If these sections be strictly construed the federal courts may hold that stch an appeal to the state district court is necessary to prevent the administrative assessment from becoming binding. The Supreme Court has held in Madisonville Traction Co. v. St. Bernard Mining Co., 196 U.S. 239 (1905), that in condemnation cases under a state's power of eminent domain, the federal courts must enforce state law. See also Clinton v. Mo. P. Ry., 122 U.S. 469 (1886). And if the condemnor has paid the damages to the sheriff and has taken possession of the property, see note 12 supra, the sheriff will, after a lapse of thirty days, pay the money to the landowner and pass title to the condemnor. See Iow 1 Code ANn. $\$ \S 472.35,472.38,472.39$ (Supp. 1954). Thus the fecteral action would be rendered moot. And the condemnor who appeals first to state district court in order to prevent the administrative determination from becoming binding may be held to have barred federal jurisdiction on the in rem theory. See notes 31-32 supra, and accompanying text. If the condemnor begins his federal court action before appealing to the state district court, his state appeal may be refused on the same in rem theory. Although that did not happen in the instant case, the problem was not presented because the case was immediately removed from the state court.

Of course it is possible that notice to the sheriff of the institution of a federal action will be interpreted as an appeal and that he will not pass title. It is also possible that the federal courts will decide that the Iowa statutes' requirement of appeal is met by instituting a federal suit. However, that this will occur is by no means certain.

38. See note 17 supra. The court felt that the railroad conld have invoked federal jurisdiction at the inception of the proceedings, Chicago, R.I. \& P.R.R. v. Katy, 107 F. Supp. 895, 904, 905 (S.D. Iowa 1952), but dismissed the action because the Iowa administrative procedure had been commenced by the railroad. However, it allowed the railrond to 
Doctrinal support for this theory might be found by reference to the Iowa rule that a condemnor who abandons state condemnation proceedings after damages have been determined is bound by that appraisal in any future attempt to condemn. ${ }^{39}$ It could be held that initiation of the federal action constitutes an abandonment of state proceedings. ${ }^{40}$ Thus, for the condemnor who has had a state administrative determination, the path to federal court is beset with legal difficulties and is perilous at best.

The condemnor who wants to secure a federal adjudication without running these risks should bypass the state administrative process and initiate his action in federal court. Compelling reasons support his right to an immediate federal adjudication. The Supreme Court has allowed defendants to remove condemnation actions from the state court to the federal district court."1 Since removal jurisdiction would have existed only if original jurisdiction were present, ${ }^{42}$ it is apparent that the federal district courts must have original jurisdiction of the proceedings at some time. Assuming that the requisites of diversity of citizenship and jurisdictional amount are met, ${ }^{43}$ the only possible

remove because it felt bound by the federal statute which granted removal only at that point in the proceedings. Id. at 907 .

39. The condemnor may abandon the proceedings at any time and decline to talie title to the property. See Iowa Cone Ans. $\$ 472.34$ (Supp. 1954); Klopp v. Chicago, M. \& S.P.R.R., 142 Iowa 474, 119 N.W. 373 (1909) (after jury verdict); Hastings v. Burlington MI.R.R, 38 Iowa 316 (1874) (abandonment after 2\%? years of occupancy by the condemnor allowed on payment of damages). Once the property is abandoned the condemnor may not recondemn the same property without being bound by the first assessment. See Robertson v. Hartenbower, 120 Iowa 410, 94 N.W. 857 (1903); Hugert v. Anderson, 35 Iowa 57S (1872).

40. If the federal court should so hold, the condemnor would be buund by the state commission's award, since federal courts in diversity cases must apply state substantive law. See note 37 sipra.

41. E.g., Mason City \& F.D.R.R. v. Boynton, 204 U.S. 570 (1907) (involving an Iowa statute identical to the one in the instant case). See alsc cases cited note 6 sufpo.

42. The removal jurisdiction of the federal courts is conferred by 28 U.S.C. $\$ 1441$ (1952):

"(a) Except as otherwise expressly provided by Act of Congress, any civil action brought in a State court of which the district courts of the United States have original jurisdicton, may be removed by the defendant or defendants, to the district court of the United States for the district and division embracing the place where such actiun is pending."

Removal of a diversity case is permitted "only if none of the parties in interest properly joined and served as defendants is a citizen of the state in which strch action

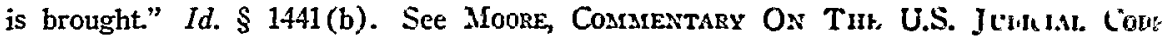
If $0.03(35)$ (1949). For a general discussion of removal jurisdiction, see Bt:si, Ju busdiction and Practice of the Courts of the United States 126-32 (5th ed. 194y).

In allowing removal of a 1905 diversity condemnation case the Supreme lisurt esplicitly held that original jurisdiction was present and that hence removal wuuld bit allowed. Madisonville Traction Co. v. St. Bernard Mining Co., 196 U.S. 239 (1905). And in 1907 the Court allowed removal of a diversity condemnation case arising umler time Iowa statute. Mason City \& F.D.R.R. v. Boynton, 204 U.S. 570 (1907).

43. For the requisites of diversity jurisdiction, see mote 1 supru 
obstacle to federal jurisdiction attaching at the outset is that compliance with Iowa administrative procedure may be held necessary to the maturing of a federal cause of action. ${ }^{44}$ Such a holding would be erroneous. The administrative remedies are merely procedural, 40 and although the Iowa legislature can prescribe rules to govern actions in its own courts, state procedure does not govern federal courts. ${ }^{48}$ Moreover, the administrative commission provided

44. This was the contention of the condemnor in the instant case. Brief for Petitioner, pp. 15-30, Chicago, R.I. \& P.R.R. v. Stude, 346 U.S. 574 (1954). This position was supported in The Supreme Court, 1953 Term, 68 HARv. L. REv. 96, 177 (1954). However. the cases cited to sustain this position by both the brief and the note are all removal cases. And the considerations involved in the determination of removal jurisdiction are materially different from those involved in the determination of original jurisdiction. There is no doubt that cases may not be removed from administrative bodies and that removal jurisdiction exists only when the proceedings become civil actions beforc a state court. See, e.g., Upshur County v. Rich, 135 U.S. 467, 471 (1890); Delaware County Comm'rs v. Diebold Safe \& Lock Co., 133 U.S. 473, 487 (1890); Boom Co. v. Patterson, 98 U.S. 403 (1878) ; Chicago, M. \& St. P. Ry. v. Drainage Dist., 253 Fed. 491, 498 (S.D. Iowa 1917). Cf. Searl v. School Dist., 124 U.S. 197, 199-200 (1888). In condemnation cases the condemnor initiates the proceedings and elects the forum. If he chooses the state procedure, the state rules are, of course, applicable. And these rules determine when condemnation proceedings become civil actions before a state court. This, however, does not imply that federal courts would be without jurisdiction of an original action until the state procedures had been complied with. The state procedture would not be involved at all in an action originally instituted in a federal court. The Federal Rules of Civil Procedure would govern the controversy. The only question involved would be whether the controversy is a civil action. See note 26 sipra. See also notes $45-48$ infra, and accompanying text. To assume that federal original jurisdiction may not be invoked at the inception of the proceedings because federal removal jurisdiction may not be invoked is to assume the very point at issue.

But see Kaw Valley Drainage Dist. v. Metropolitan Water Co., 186 Fed. 315, 323 (8th Cir. 1911) (dictum) ; Hartford v. Montague, 94 Fed. 227, 228 (C.C.D. Conn. 1899) (same).

45. The procedures to be followed are established by a chapter of the Iowa statute labeled "Procedure Under Power of Eminent Domain." Iowa Cone ANv. c. 472 (Supp. 1954). The substantive right to condemn property is granted in a different chapter of the statute. $I d$. $\$ 471.6$. And once this right exists the railroad has a civil cause of action which may be adjudicated in federal court. See cases cited note 46 infra.

There are no reasons to believe that the Iowa procedure was intended to be a condition precedent to the accrual of a civil action triable in the federal courts. Since under FEv. R. CIv. P. 71A(k), the federal district court must provide a commission assessment before trial, see note 1 supra, there appear no reasons for any court to insist on exhaustion of the identical state proceedings.

46. Federal court procedure is established in the Federal Rules of Civil Procedure. Rules to govern the situation in the instant case are established in FED. R. Clv. P. 71A(k). See note 1 supra. Indeed, the very purpose of Rule $71 \mathrm{~A}$ was to eliminate the necessity of procedural conformity to state statutes, which was previously required in condemmintion cases by the Conformity Statute. Act of August 1, 1898, c. 278, 25 Srit. 357. Sce Advisory Committee on Ruties For Civil. Proceduke, Suppleanentary Report or Phoposed Rule to Govern Condemnation Cases in the United States District Coukas 18-25 (March 1951).

And, of course, state statutes may not deprive the federal courts of jurisdiction over civil actions. Southern Pac. Co. v. Denton, 146 U.S. 202 (1892); Hess v. Reynolds, 113 
by the Iowa statute is an ad hoc body without expertise ; $^{\mathbf{7}}$ its appraisal should not be considered the type of administrative remedy that must be exhausted before recourse may be had to the federal courts. ${ }^{18}$ However, even should a federal court reject these arguments and dismiss the condemnor's suit, he will undoubtedly be able to invoke federal jurisdiction aiter he completes the state administrative process. ${ }^{49}$ On the other hand, if the condemnor does not institute a federal action until after the state proceedings, he runs the risk of a dismissal which would permanently bar him from federal court.

Condemnation cases are likely to provoke local prejudice. ${ }^{.0}$ Diversity jurisdiction enables a party to avoid the effect of such bias on judicial actions. Hence, it is probable that if federal condemnation procedure were clarified, more diversity condemnors would seek adjudication in the federal district courts. In defining this procedure, courts should assure the condemnor who fears local antagonism the right to choose his forum at the inauguration of the proceedings.

U.S. 73 (1885). See also Madisonville Traction Co. v. St. Bernard Mining Co., 196 U.S. 239, 256 (1905) ; Mineral Range R.R. v. Detroit \& Lake Superior Copper Co., 25 Fed. 515 (C.C.T.D. Mich. 1885).

47. The commission consists of six resident freeholders picked for the assessment by the sheriff. Tows CODE AxN. $\$ 472.4$ (Supp. 1954).

Of the states which require commissions, most provide for an ad hoc commission of three men. See Clark, The Proposed Condenuation Rule, 10 Orno St. L.J. 1, 9 (1949). See also 6 Nichols, Earinent Domatm $\$ 26.53$ (3d ed. 1953).

48. The requirement that administrative remedies must be exhausted before access to the federal courts will be allowed is commonly applied in equity cases. Sec Eerger. Exhaustion of Administrative Remedies, 48 YAIE L.J. 981, 985-86 (1939). Federal csurts were loath to enjoin the state legislative process, which was being carried on by the states' administrative bodies. See Prentis v. Atlantic Caast Line Ry., 211 U.S. 210 (1908). The primary jurisdiction of the state administrative bodies was based on considerations of convenient and orderly procedure and the belief that the decision of state appointed experts might render resort to the courts unnecessary. Berger, supra at 1005. None of these considerations seems applicable to the administrative procedure provided by the Iowa statute. Rule $71 \mathrm{~A}(\mathrm{k})$ provides for resort to the same type of commission before a jury trial may be had. See note 1 supra. See generally Davis, Adarsistmatrie LAW c. 15 (1951).

49. It is hardly conceivable that a court would use the exhaustion of administrative remedie's doctrine to deny a condemnor access to the federal courts before communcenent of state proceedings, and then dismiss the same person's suit at the completion of state procedure on the theory that he had irrevocably elected state remedies. This would deny to a condemnor the right to a federal trial which is granted to him by 28 U.S.C. $\$ 1332$ (1952) with procedure set out in Rule $71 \mathrm{~A}(\mathrm{k})$. See note 1 supro.

50. In the instant case, for example, the railroad was building approximately thirtyfour miles of new line in two Iowa counties and abandoning an approximately equal mileage in the same counties. Evidently much opposition arose from the people served by the original line. Since the jury in the state court would be composed of prople from this area, the railroad desired a federal adjudication. Letter from A. B. Howland, counsel for the railroad, to the Yale Law Journal, dated March 22, 1954, on file in Yale Law Library. Although the federal court's appointed commission might be made up of local people, the trial jury would probably be selected from a much wider area.

51. See note 49 supra. See also Mradisonville Traction Co. v. St. Bernard Mimug Co., 196 U.S. 239, 253-54 (1905). 